\title{
A potential commercial use of cajeta (a traditional milk product from Mexico) in the development of whey beverages
}

\author{
Jahir Antonio BARAJAS-RAMÍREZ1, Carolina RAMÍREZ-LÓPEZ², Victoria Guadalupe AGUILAR-RAYMUNDO ${ }^{1 *}$
}

\begin{abstract}
Cajeta is a Mexican artisanal candy elaborated from goat milk. While it is popular among consumers, it is necessary to find alternative uses to improve access to stable and fair trade for producers. Therefore, the objective of this study was to develop a functional beverage using whey with different levels of inulin (4, 8 and 12\%) as a prebiotic, guar gum $(0.321,0.625$ and $1.25 \%)$ as a thickener and cajeta $(20 \% \mathrm{v} / \mathrm{v})$ as flavoring. Nine formulations were prepared, stored at $4{ }^{\circ} \mathrm{C}$ and analyzed on days 0,7 and 14. The $\mathrm{pH}$ values were constant (5.9) in all formulations, while acidity exhibited changes on days 0 and 14 . Flow properties of the beverages exhibited a non-Newtonian behavior and fitted best with the Power Law (PL). According to acceptance tests and a Check-All-That-Apply (CATA) questionnaire, it was possible to obtain a cajeta-flavored whey-beverage using lower concentrations of inulin and gum. The physicochemical characteristics provided by ingredients added in lower concentrations did not affect the organoleptic properties of the product, showed lower viscosity, and were highly accepted by most participants.
\end{abstract}

Keywords: Cajeta; whey beverage; inulin; guar gum; physicochemical characteristics; sensory properties.

Practical Application: The combination of cajeta, whey, and hydrocolloids is a viable alternative since the commercialization of cajeta as part of the whey beverage is potentialized.

\section{Introduction}

Nowadays, the demand for foods with functional properties is increasing around the world. Flavored energy drinks, and/or beverages with added fibers, oligosaccharides, or fermented beverages with prebiotics and probiotics are some examples of products that have been developed (Molero \& Briñez, 2018). Dulce de leche (milk jam, milk caramel) is a form of sweetened condensed milk that is very popular in countries such as Mexico, Argentina, and Brazil, and may be produced from cow or goat milk (Park \& Haenlein, 2013). The changes in consumer preferences associated with the low consumption of sugars has led to a decrease in demand for these types of products, meaning that alternatives are sought for consumption without negatively effecting the consumer's health.

Whey is a by-product of the cheese industry with a high production worldwide. It is characterized as being an industrial effluent, with a high biochemical oxygen demand due to its high organic compound content, which in turn makes it one of the most polluting by-products (Panghal et al., 2017). Whey contains more than half the nutrients of milk, such as salts, vitamins, lactose, enzymes, and proteins rich in essential amino acids. Furthermore, a group of bioactive compounds derived from whey were studied for their potential health benefits, such as enhancing the immune function and modulating the adiposity and antioxidant capacity (Ha \& Zemel, 2003; Chavan et al., 2015a; Arranz et al., 2019). Whey-based drinks have entered the market because of their functional potential and the fact that they are accepted by different consumer groups (Castro et al., 2009;
Guimarães et al., 2019). While recent data suggests that their consumption is growing worldwide, this type of product is mainly present in the sports nutrition market (Ha \& Zemel, 2003; Janiaski et al., 2016).

Some of the whey-cheese-based beverages incorporate microorganisms which generate fermented beverages, however some research has been conducted to analyze the effects of adding fruit pulp such as banana (Dhamsaniya \& Varshney, 2013), mango (Ismail et al., 2011; Sakhale et al., 2012; Chavan et al., 2015b), pineapple (Shukla, 2012; Baljeet et al., 2013) as well as other artificial and natural flavorings.

On the other hand, high-intensity ultrasound technology (HIUS) has been intensively studied in recent years and applied in different food systems. Guimarães et al. (2019), evaluated the nutritional profile and volatile compounds present in a prebiotic (inulin) soursop whey beverage in the presence of high-intensity ultrasound as compared to conventional high-temperature short time. Monteiro et al. (2020), analyzed the physicochemical, microstructural, and sensory characteristics of a chocolate whey beverage processed using HIUS technology. Both results highlight the feasibility of using ultrasound in manufacturing functional dairy products, with therapeutic properties, preservation of nutritional compounds of the food.

The use of sensory evaluation techniques in the development and optimization of food products can help to identify the characteristics that lead to their greater acceptance by consumers 
(Ares \& Jaeger, 2013; Li et al., 2015), while manufacturers are increasingly interested in the final consumers' opinions and expectations of their products (Parente et al., 2011). Furthermore, the use of consumer tests and classification techniques are useful for identifying niches of consumers according to their preferences (Berget, 2018), which could in turn help steer the food manufacturers' efforts in the right direction with regard to product development (Parente et al., 2011; Bruzzone et al., 2015).

Therefore, the objective of this work was to develop and characterize a whey-based beverage flavored with Mexican caramel jam ("cajeta") by determining the physicochemical, flow behavior, and sensory properties with regard to time, generating a novel product using whey as a potential functional and sustainable ingredient.

\section{Materials and methods}

\subsection{Raw materials}

Whey was kindly provided by a small company that makes fresh cheese. Dairy beverage formulations were prepared by using skimmed milk powder (Svelty, Nestlé, Mexico), Inulin (Tequilera Real de Penjamo, Guanajuato, Mexico.), guar gum (HSN Foods) and cajeta (a type of artisanal candy elaborated with goat milk) which was used in this formulation as a flavoring agent (Arandas, Guanajuato, Mexico). Physicochemical analyses were determined for cheese whey to adjust the solids using a lactoscan (Milkanalyzer, 6527, Nova Zagora, Bulgaria).

\subsection{Whey beverage preparation}

Firstly, the whey is filtered using muslin cloth. For preparing the beverages were formulated from pasteurized liquid whey $\left(65{ }^{\circ} \mathrm{C} / 30 \mathrm{~min}\right.$ ). The milk powder (solids $15 \% \mathrm{w} / \mathrm{v}$ ) was add and dissolved in the whey before all ingredients, then inulin (4, 8 and $12 \% \mathrm{w} / \mathrm{v})$, guar gum $(0.321,0.625$ and $1.25 \% \mathrm{w} / \mathrm{v})$, and flavor (cajeta, $20 \% \mathrm{v} / \mathrm{v}$ ), were adding to whey and mixed with a manual mixer (model BL687CO, Massachusetts, USA), each batch of bottles was filled and pasteurized a $65^{\circ} \mathrm{C} / 30 \mathrm{~min}$ and finally were stored $\left(4 \pm 2{ }^{\circ} \mathrm{C}\right)$ for further analysis.

\subsection{Physicochemical analysis}

The $\mathrm{pH}$ was determined at $20^{\circ} \mathrm{C}$ with a digital potentiometer (model HI 98107; HANNA, Italy) which had been previously calibrated. The acidity was measured by titration of a $10 \mathrm{~mL}$ sample with $\mathrm{NaOH}(0.1 \mathrm{~N})$ and phenolphthalein as an indicator (0.1\%) using method 16.023 (Association of Official Analytical Chemists, 1980). Total solids were determined using a digital refractometer (A. Krüss $0-90^{\circ}$ Brix, DR 201-95-OE, Hamburg), while measurements were made in both whey and beverage formulations after 0,7 , and 14 days of storage.

\subsection{Flow properties}

Flow properties for the whey-based beverages were carried out in a Brookfield DV-II + Pro viscometer (Brookfield
Engineering Laboratories Inc., MA, USA) using a sample of $120 \mathrm{~mL}$. Shear stress $(\tau)$ was determined at the correspondent shear rates $(\gamma)$ obtained from readings at $6,12,30,50$ y $100 \mathrm{rpm}$ at $20^{\circ} \mathrm{C}$, as well as applying the corresponding relationships provided by the manufacturer (Brookfield, 2011) (Equations 1-3).

$\gamma=\frac{2 \omega R_{C}^{2} R_{b}^{2}}{R_{b}^{2}\left(R_{C}^{2}-R_{b}^{2}\right)}$

$\omega=\frac{2 \pi N}{60}$

$$
\tau=\frac{M\left(\frac{\text { reading }}{100}\right)}{2 \pi R_{b}^{2} L}
$$

where, $\gamma$ : shear rate $(1 / \mathrm{s}) ; \omega$ : spindle angular velocity $(\mathrm{rad} / \mathrm{s}) ; \mathrm{R}_{c}$ : container radius $(m), R_{b}$ : spindle radius $(m), N$ : spindle speed (rpm), $\tau$ : Shear stress (Pa), L: spindle height (m). M: torque for this viscometer $=6.73 \times 10^{-5}(\mathrm{~N} \cdot \mathrm{m})$.

The experimental flow responses or rheograms were fitted to three mathematical relationships, which were the Power Law (PL), Herschel-Bulkley (HB) and Bingham plastic (BP) models.

Two goodness of fit tests were applied to the obtained experimental data, the percentage of the mean error (PEM, Equation 4) and the root- mean-square error (RMSE, Equation 5), to verify the fit of each model to the rheological behavior of each dairy beverage:

$$
\begin{aligned}
& P E M=\frac{100}{n_{e}} \sum_{i=l}^{n_{e}}\left(\frac{\tau_{\text {exp }-} \tau_{\text {pred }}}{\tau_{\text {exp }}}\right) \\
& R S M E=\frac{1}{n_{e}} \sum_{i=1}^{n_{e}}\left(\left(\tau_{\text {exp- }} \tau_{\text {pred }}\right)^{2}\right)^{1 / 2}
\end{aligned}
$$

where: $\tau_{\exp }=$ experimental shear stress $(\mathrm{Pa}) ; \tau_{\text {pred }}=$ predicted shear stress (from the applied model, $\mathrm{Pa}$ ); and $n_{\mathrm{e}}=$ the number from the experimental data (from the flow curve, dimensionless).

\subsection{Sensory acceptance and characterization}

Firstly, a session was conducted to obtain the characteristics for describing the beverages formulated. At this stage, 20 participants (11 females: 9 males, aged 20-49 years old) received a $30 \mathrm{~mL}$ sample of the nine beverages with three-digit randomized numbers. Subjects were asked to write on a white sheet of paper all the perceived characteristics of appearance, smell, texture, and taste that could help to discriminate between samples. A list of attributes was obtained and the most frequently mentioned were selected for inclusion in a Check-All-That-Apply (CATA) questionnaire.

One hundred and twenty subjects participated in the study, each receiving a $20 \mathrm{~mL}$ sample of each of the nine beverage formulas. After tasting, subjects indicated the acceptance for the samples 
by a rank-rating procedure (O'Mahony \& Wichchukit, 2017), ordering the samples from the least to the most preferred and by rating them from the least to the most accepted in a 15-point scale. After the participants had completed the acceptance test, they received a CATA questionnaire with the attributes obtained from a previous stage and were asked to check which characteristics they perceived from each sample. To determine how much the beverages differed from their ideal product, subjects were invited to check the attributes that must and must not be present in their ideal beverages. In all cases, the samples were presented to the participants in a counterbalanced and randomized order and were evaluated 7 days after they were made.

The frequencies of mentions for the characteristics perceived in the beverages by consumers were submitted to a Principal Component Analysis in order to obtain the main sensory attributes as well as their relationship with physicochemical characteristics and to then associate them with preference.

\subsection{Statistical analysis}

All systems were analyzed after preparation on days 0,7 , and 14 of storage, were conducted in triplicate and expressed as means \pm SE of at least three independent experiments. The response variables identified as physicochemical and flow properties were statistically examined using the Minitab software (v.16, Minitab Inc., Pennsylvania, USA). Statistical analysis was performed using an analysis of variance (ANOVA) while a Tukey's test was applied for carrying out multiple comparisons of the mean values. Data obtained by the application of acceptance tests were analyzed with Kruskal-Wallis and Duncan's tests for a means comparison. Furthermore, a principal component analysis was performed to analyze the relationship between instrumental and sensory measurements. In addition, correspondence analysis was applied to determine the spatial configuration of attributes, products and acceptance as perceived by consumers. Finally, statistical analysis on the sensory data was carried out using the XLSTAT system (Addinsoft, France) with a level significance of $\mathrm{p}<0.05$.

\section{Results and discussion}

\subsection{Physicochemical analysis on cheese whey}

The physicochemical characteristics of liquid whey were assessed for quality attributes with the results indicating $\mathrm{pH}$ (5.2), acidity $(0.19 \%)$, total solids $(6.41 \%)$, fat $(0.21 \%)$, protein (2.63\%), ash (0.54\%) and lactose (3.70\%). The results of the liquid whey characterization obtained by Yasmin et al. (2013) showed similar values to those obtained in this study: $\mathrm{pH}$ (5.24), acidity (0.29\%), total acids (6.49\%), fat (0.25\%), ash $(0.56 \%)$ and protein (0.81\%). In another study, Sakhale et al. (2012) characterized the liquid whey in their study and observed $0.19 \%$ fat, $0.45 \%$ protein, $5.73 \%$ SNF and $6.12 \%$ total solids.

\subsection{Physicochemical analysis during refrigerated storage}

The effect of adding inulin, guar gum, and cajeta on the physicochemical parameters of the beverages and their changes during storage was studied and results are shown in Table 1. The physicochemical properties of all formulations exhibited a constant $\mathrm{pH}$ (5.9) throughout refrigerated storage (Table 1). By contrast, the acidity values increased $(p<0.05)$ in all formulations on day 14 of refrigerated storage. Although there is a reported $\mathrm{pH}$ and acidity stabilization in dairy beverages during storage (Silveira et al., 2015; Gomes et al., 2013), in this study the acidity increased due to components of beverage formulation. Reported acidity values for fermented beverages range from $0.74-0.82 \%$, which are strongly influenced by the components used, the amount of milk solids added, and the metabolic activity of microorganisms responsible for fermentation (Thamer \& Penna, 2006). As expected, the solid contents in the formulations made with inulin and gum were higher than the control $(p<0.05)$ due to the incorporation of stabilizing agents. These results differ from those reported by Chatterrjee et al. (2015) who observed a decrease in $\mathrm{pH}$ values, an increase in titratable acidity expressed as citric acid, and an increase in soluble solid content determined after 11 days of storage.

Table 1. Physicochemical properties of formulations stored at $4{ }^{\circ} \mathrm{C}$ for 14 days.

\begin{tabular}{|c|c|c|c|c|}
\hline Formulation & Days & $\mathrm{pH}$ & TA (\%) & ${ }^{\circ}$ Brix \\
\hline \multirow{3}{*}{$\mathrm{C}(\mathrm{I} 0$ + G0) } & 0 & $5.9 \pm 0.01^{\mathrm{abA}}$ & $0.20 \pm 0.1^{\mathrm{aA}}$ & $12.9 \pm 0.26^{\mathrm{aA}}$ \\
\hline & 7 & $5.9 \pm 0.02^{\mathrm{abA}}$ & $0.20 \pm 0.1^{\mathrm{aA}}$ & $12.9 \pm 0.66^{\mathrm{a}^{\mathrm{A}}}$ \\
\hline & 14 & $5.9 \pm 0.00^{\mathrm{abA}}$ & $0.19 \pm 0.1^{\mathrm{a} B}$ & $12.9 \pm 0.25^{\mathrm{a}^{\mathrm{A}}}$ \\
\hline \multirow{3}{*}{$\begin{array}{l}\mathrm{F} 1(\mathrm{I} 4+ \\
\mathrm{G} 0.312)\end{array}$} & 0 & $5.9 \pm 0.01^{\mathrm{abA}}$ & $0.32 \pm 0.2^{\mathrm{aA}}$ & $28.2 \pm 0.15^{\mathrm{bA}}$ \\
\hline & 7 & $5.9 \pm 0.02^{\mathrm{abA}}$ & $0.22 \pm 0.1^{\mathrm{aA}}$ & $22.8 \pm 4.36^{\mathrm{bA}}$ \\
\hline & 14 & $5.9 \pm 0.00^{\mathrm{abA}}$ & $0.43 \pm 0.0^{\mathrm{aB}}$ & $23.2 \pm 0.70^{\mathrm{bA}}$ \\
\hline \multirow{3}{*}{$\begin{array}{l}\mathrm{F} 2(\mathrm{I} 4+ \\
\text { G0.625) }\end{array}$} & 0 & $5.9 \pm 0.01^{\mathrm{abA}}$ & $0.29 \pm 0.2^{\mathrm{aA}}$ & $23.6 \pm 0.70^{\mathrm{bA}}$ \\
\hline & 7 & $5.9 \pm 0.02^{\mathrm{abA}}$ & $0.23 \pm 0.1^{\mathrm{aA}}$ & $22.8 \pm 0.52^{\mathrm{bA}}$ \\
\hline & 14 & $5.9 \pm 0.00^{\mathrm{abA}}$ & $0.37 \pm 0.1^{\mathrm{aB}}$ & $23.3 \pm 0.35^{\mathrm{bA}}$ \\
\hline \multirow{3}{*}{$\begin{array}{l}\mathrm{F} 3(\mathrm{I} 4+ \\
\mathrm{G} 1.25)\end{array}$} & 0 & $5.9 \pm 0.01^{\mathrm{abA}}$ & $0.13 \pm 0.1^{\mathrm{aA}}$ & $28.2 \pm 1.70^{\mathrm{bA}}$ \\
\hline & 7 & $5.9 \pm 0.02^{\mathrm{abA}}$ & $0.22 \pm 0.1^{\mathrm{aA}}$ & $22.6 \pm 0.20^{\mathrm{bA}}$ \\
\hline & 14 & $5.9 \pm 0.00^{\mathrm{abA}}$ & $0.37 \pm 0.1^{\mathrm{aB}}$ & $25.1 \pm 0.90^{\mathrm{bA}}$ \\
\hline \multirow{3}{*}{$\begin{array}{l}\mathrm{F} 4(\mathrm{I} 8+ \\
\mathrm{G} 0.312)\end{array}$} & 0 & $5.9 \pm 0.01^{\mathrm{abA}}$ & $0.34 \pm 0.0^{\mathrm{aA}}$ & $28.50 \pm 0.30^{\mathrm{bA}}$ \\
\hline & 7 & $5.9 \pm 0.02^{\mathrm{abA}}$ & $0.22 \pm 0.0^{\mathrm{aA}}$ & $25.40 \pm 0.20^{\mathrm{bA}}$ \\
\hline & 14 & $5.9 \pm 0.00^{\mathrm{abA}}$ & $0.44 \pm 0.1^{\mathrm{aB}}$ & $24.6 \pm 0.80^{\mathrm{bA}}$ \\
\hline \multirow{3}{*}{$\begin{array}{l}\text { F5 (I8 + } \\
\text { G0.625) }\end{array}$} & 0 & $5.9 \pm 0.01^{\mathrm{aA}}$ & $0.27 \pm 0.1^{\mathrm{aA}}$ & $26.9 \pm 0.34^{\mathrm{bA}}$ \\
\hline & 7 & $5.9 \pm 0.02^{\mathrm{aA}}$ & $0.26 \pm 0.1^{\mathrm{aA}}$ & $26.9 \pm 2.50^{\mathrm{bA}}$ \\
\hline & 14 & $6.0 \pm 0.00^{\mathrm{aA}}$ & $0.33 \pm 0.1^{\mathrm{aB}}$ & $23.5 \pm 0.70^{\mathrm{bA}}$ \\
\hline \multirow{3}{*}{$\begin{array}{l}\text { F6 (I8 + } \\
\text { G1.25) }\end{array}$} & 0 & $5.9 \pm 0.01^{\mathrm{abA}}$ & $0.15 \pm 0.1^{\mathrm{aA}}$ & $27.2 \pm 1.40^{\mathrm{bA}}$ \\
\hline & 7 & $5.9 \pm 0.02^{\mathrm{abA}}$ & $0.22 \pm 0.1^{\mathrm{aA}}$ & $24.9 \pm 0.10^{\mathrm{bA}}$ \\
\hline & 14 & $5.9 \pm 0.00^{\mathrm{abA}}$ & $0.43 \pm 0.1^{\mathrm{aB}}$ & $23.6 \pm 0.55^{\mathrm{bA}}$ \\
\hline \multirow{3}{*}{$\begin{array}{l}\text { F7 (I12 + } \\
\text { G0.312) }\end{array}$} & 0 & $5.9 \pm 0.01^{\mathrm{abA}}$ & $0.35 \pm 0.1^{\mathrm{aA}}$ & $22.9 \pm 0.37^{\mathrm{bA}}$ \\
\hline & 7 & $5.9 \pm 0.02^{\mathrm{abA}}$ & $0.23 \pm 0.1^{\mathrm{aA}}$ & $26.0 \pm 0.20^{\mathrm{bA}}$ \\
\hline & 14 & $5.9 \pm 0.00^{\mathrm{abA}}$ & $0.34 \pm 0.1^{\mathrm{aB}}$ & $25.5 \pm 1.00^{\mathrm{bA}}$ \\
\hline \multirow{3}{*}{$\begin{array}{l}\mathrm{F} 8(\mathrm{I} 12+ \\
\text { G0.625) }\end{array}$} & 0 & $5.9 \pm 0.01^{\mathrm{abA}}$ & $0.28 \pm 0.0^{\mathrm{aA}}$ & $25.5 \pm 0.80^{\mathrm{bA}}$ \\
\hline & 7 & $5.9 \pm 0.02^{\mathrm{abA}}$ & $0.23 \pm 0.1^{\mathrm{aA}}$ & $26.0 \pm 0.20^{\mathrm{bA}}$ \\
\hline & 14 & $5.9 \pm 0.00^{\mathrm{abA}}$ & $0.35 \pm 0.1^{\mathrm{aB}}$ & $24.3 \pm 2.10^{\mathrm{bA}}$ \\
\hline \multirow{3}{*}{$\begin{array}{l}\text { F9 (I12 + } \\
\text { G1.25) }\end{array}$} & 0 & $5.9 \pm 0 . .^{01 \mathrm{aA}}$ & $0.17 \pm 0.0^{\mathrm{aA}}$ & $28.2 \pm 4.70^{\mathrm{bA}}$ \\
\hline & 7 & $5.9 \pm 0.02^{\mathrm{aA}}$ & $0.22 \pm 0.1^{\mathrm{aA}}$ & $25.7 \pm 0.30^{\mathrm{bA}}$ \\
\hline & 14 & $5.9 \pm 0.00^{\mathrm{aA}}$ & $0.26 \pm 0.1^{\mathrm{a} B}$ & $25.9 \pm 1.60^{\mathrm{bA}}$ \\
\hline
\end{tabular}

Values are expressed as means \pm standard deviation $(n=3) . T A=$ titratable acidity, $\mathrm{I}=$ inulin $(4,8,12 \%) ; \mathrm{G}=$ guar gum $(0.312,0.625,1.25 \%)$. Different letters indicate a significant difference $(\mathrm{p}<0.05)$. Different superscript letters in the same column indicate a significant difference between formulations $(\mathrm{p}<0.05)$ by Tukey's test. Lower case letters = differences between treatments, upper case letters = differences during storage 


\subsection{Flow properties}

The analyzed systems showed different trends due to the proportion of solids affecting particle interactions and product consistency. All beverages exhibited a pseudo-plastic behavior with or without yield stress depending on the model fitting, a characteristic which was reported other studies (Guimarães et al., 2018).

The flow properties obtained by applying Power Law (PL), Herschel-Bulkley (HB) and Bingham Plastic (BP) equations are given in Table 2. All formulations presented a shear-thinning non-Newtonian response $(\mathrm{n}<1)$, where the difference between both models is expressed by the presence or consideration of the yield stress, which is part of the HB model. The values of the consistency coefficient $(K)$ ranged from 1.80 (F2 on day 0 ) to $30.64 \mathrm{~Pa} \mathrm{~s}^{\mathrm{n}}$ (F6 on day 0 ) with PL which are notably different to the data for the HB model. This was due to the presence of yield stress which ranged from 0.41 (F1 on day 0 ) to $13.60 \mathrm{~Pa}$ (F2 on day 14).

The increase of this rheological parameter is an indicator of an increase in total solid content or a decrease in particle content, as these samples are more viscous. From F4 to F9, the increase in solids and interactions between the drink components can be observed (Figure 1). Flow parameters on days 0,7 , and 14 for goodness determinations indicate that all systems had a better fit for the PL model. However, they also showed an excellent fit for both the HB and BP models.

The interactions of inulin and guar gum influenced the rheological parameters of the flavored beverage, which may be related to structural changes, thereby generating gel formation. These results were also observed by Guimãraes et al. 2015 in the elaboration of a drink based on whey with added acacia gum and gellan gum. The addition of inulin as a stabilizing agent is beneficial, as some authors indicate that the consumption of 4 - $5 \mathrm{~g}$ of fructans per day is enough for to be considered a prebiotic (Rao, 2001; Roberfroid, 1999). According to this study, the consumption of F1 (4\% inulin and 0.312 gum guar) is recommended. Grom et al. (2020), note that the whey-based beverage showed a reduction in blood glucose levels compared to consumption of bread alone, suggesting that this dairy matrix can control blood glucose.

\subsection{Sensory characteristics}

Twenty subjects participated in the test aimed at obtaining the sensory descriptors for the beverages. Eleven attributes, chosen for their frequency of mentions, were considered as

Table 2. Flow parameters with Power Law (PL), Herschel-Bulkley (HB) and Bingham Plastic (BP) models for dairy beverages stored after 14 days.

\begin{tabular}{|c|c|c|c|c|c|c|c|c|c|c|c|}
\hline \multirow{2}{*}{ Formulation } & \multirow{2}{*}{ Days } & \multicolumn{3}{|c|}{$\mathrm{PL}$} & \multicolumn{4}{|c|}{$\mathrm{HB}$} & \multicolumn{3}{|c|}{$\mathrm{BP}$} \\
\hline & & $\mathrm{n}$ & $\mathrm{K}\left(\mathrm{Pa} \mathrm{s}^{\mathrm{n}}\right)$ & RMSE & $\tau_{0}(\mathrm{~Pa})$ & $\mathrm{n}$ & $\mathrm{K}\left(\mathrm{Pa} \mathrm{s}^{\mathrm{n}}\right)$ & RMSE & $\tau_{0}(\mathrm{~Pa})$ & $\eta_{\mathrm{p}}\left(\mathrm{Pa} \mathrm{s}^{\mathrm{n}}\right)$ & RMSE \\
\hline \multirow{3}{*}{$\mathrm{F} 1(\mathrm{I} 4+\mathrm{G} 0.312)$} & 0 & 0.68 & 0.07 & 0.04 & 0.41 & 0.72 & 0.60 & 0.03 & 0.80 & 0.02 & 0.05 \\
\hline & 7 & 0.61 & 0.08 & 0.06 & 0.68 & 0.73 & 0.26 & 0.08 & 0.10 & 0.10 & 0.08 \\
\hline & 14 & 0.68 & 0.08 & 0.09 & 6.8 & 0.67 & 2.46 & 0.06 & 0.11 & 0.20 & 0.01 \\
\hline \multirow{3}{*}{ F2 (I4 + G0.625) } & 0 & 0.39 & 1.80 & 0.01 & 1.17 & 0.65 & 0.76 & 0.03 & 1.93 & 0.26 & 0.04 \\
\hline & 7 & 0.31 & 1.70 & 0.04 & 1.33 & 0.49 & 0.69 & 0.06 & 1.95 & 0.16 & 0.06 \\
\hline & 14 & 0.23 & 17.75 & 0.71 & 13.6 & 0.54 & 4.86 & 0.67 & 17.62 & 1.42 & 0.59 \\
\hline \multirow{3}{*}{ F3 (I4 + G1.25) } & 0 & 0.13 & 59.38 & 0.19 & 52.74 & 0.55 & 8.09 & 0.24 & 60.59 & 2.06 & 0.40 \\
\hline & 7 & 0.13 & 56.89 & 1.06 & 49.76 & 0.55 & 8.18 & 1.01 & 57.39 & 2.27 & 0.95 \\
\hline & 14 & 0.13 & 50.83 & 1.74 & 44.02 & 0.47 & 7.71 & 1.76 & 50.44 & 2.17 & 1.58 \\
\hline \multirow{3}{*}{$\mathrm{F} 4(\mathrm{I} 8+\mathrm{G} 0.312)$} & 0 & 0.5 & 6.62 & 0.20 & 3.34 & 0.58 & 3.34 & 0.47 & 8.35 & 1.45 & 0.47 \\
\hline & 7 & 0.54 & 6.82 & 1.87 & 4.76 & 0.86 & 2.45 & 2.21 & 11.5 & 1.01 & 2.07 \\
\hline & 14 & 0.59 & 6.77 & 0.31 & 3.43 & 0.78 & 3.74 & 0.64 & 8.82 & 1.53 & 0.63 \\
\hline \multirow{3}{*}{ F5 (I8 + G0.625) } & 0 & 0.4 & 26.00 & 0.45 & 18.89 & 0.70 & 8.80 & 1.43 & 32.06 & 2.71 & 1.62 \\
\hline & 7 & 0.41 & 21.33 & 2.31 & 16.97 & 0.81 & 5.57 & 3.45 & 30.27 & 1.95 & 3.06 \\
\hline & 14 & 0.45 & 19.56 & 0.25 & 12.58 & 0.70 & 8.36 & 0.79 & 23.77 & 2.73 & 1.04 \\
\hline \multirow{3}{*}{ F6 (I8 + G1.25) } & 0 & 0.44 & 14.22 & 0.38 & 9.64 & 0.72 & 5.52 & 1.00 & 18.00 & 1.82 & 1.08 \\
\hline & 7 & 0.18 & 45.88 & 0.50 & 41.93 & 0.71 & 5.16 & 1.42 & 51.43 & 1.42 & 1.28 \\
\hline & 14 & 0.19 & 45.37 & 0.44 & 40.91 & 0.68 & 6.06 & 1.22 & 51.26 & 1.59 & 1.22 \\
\hline \multirow{3}{*}{ F7 (I12 + G0.312) } & 0 & 0.29 & 30.64 & 0.30 & 25.35 & 0.68 & 6.88 & 1.10 & 36.24 & 1.91 & 1.19 \\
\hline & 7 & 0.62 & 2.88 & 0.49 & 1.62 & 0.85 & 1.42 & 0.68 & 4.59 & 0.62 & 0.57 \\
\hline & 14 & 0.55 & 3.21 & 0.67 & 2.42 & 1.01 & 0.83 & 1.06 & 5.64 & 0.45 & 0.74 \\
\hline \multirow{3}{*}{$\mathrm{F} 8(\mathrm{I} 12$ + G0.625) } & 0 & 0.26 & 34.74 & 2.51 & 33.03 & 1.37 & 1.16 & 6.06 & 45.67 & 1.26 & 3.16 \\
\hline & 7 & 0.42 & 22.50 & 0.25 & 15.53 & 0.7 & 8.51 & 1.01 & 27.62 & 2.67 & 1.23 \\
\hline & 14 & 0.42 & 22.05 & 0.22 & 15.05 & 0.69 & 8.52 & 0.95 & 26.98 & 2.68 & 1.20 \\
\hline \multirow{3}{*}{ F9 (I12 + G1.25) } & 0 & 0.35 & 23.88 & 0.38 & 18.29 & 0.69 & 7.07 & 1.35 & 29.03 & 2.08 & 1.49 \\
\hline & 7 & 0.24 & 37.18 & 0.58 & 32.86 & 0.75 & 5.37 & 1.67 & 43.61 & 1.65 & 1.40 \\
\hline & 14 & 0.25 & 36.34 & 0.33 & 28.39 & 0.64 & 8.94 & 0.64 & 38.13 & 2.77 & 0.75 \\
\hline
\end{tabular}

Values represent the mean of triplicate analysis. I =inulin ( $4,8,12 \%) ; \mathrm{G}=$ guar gum $(0.312,0.625,1.25 \%) . K$ : consistency coefficient $\left(\mathrm{Pa} \cdot \mathrm{s}^{\mathrm{n}}\right) ; n$ : flow behavior index $($ dimensionless); $\tau$ : yield stress $(\mathrm{Pa})$ and $\eta_{\mathrm{p}}$ :plastic viscosity $(\mathrm{Pa} \cdot \mathrm{s})$. 

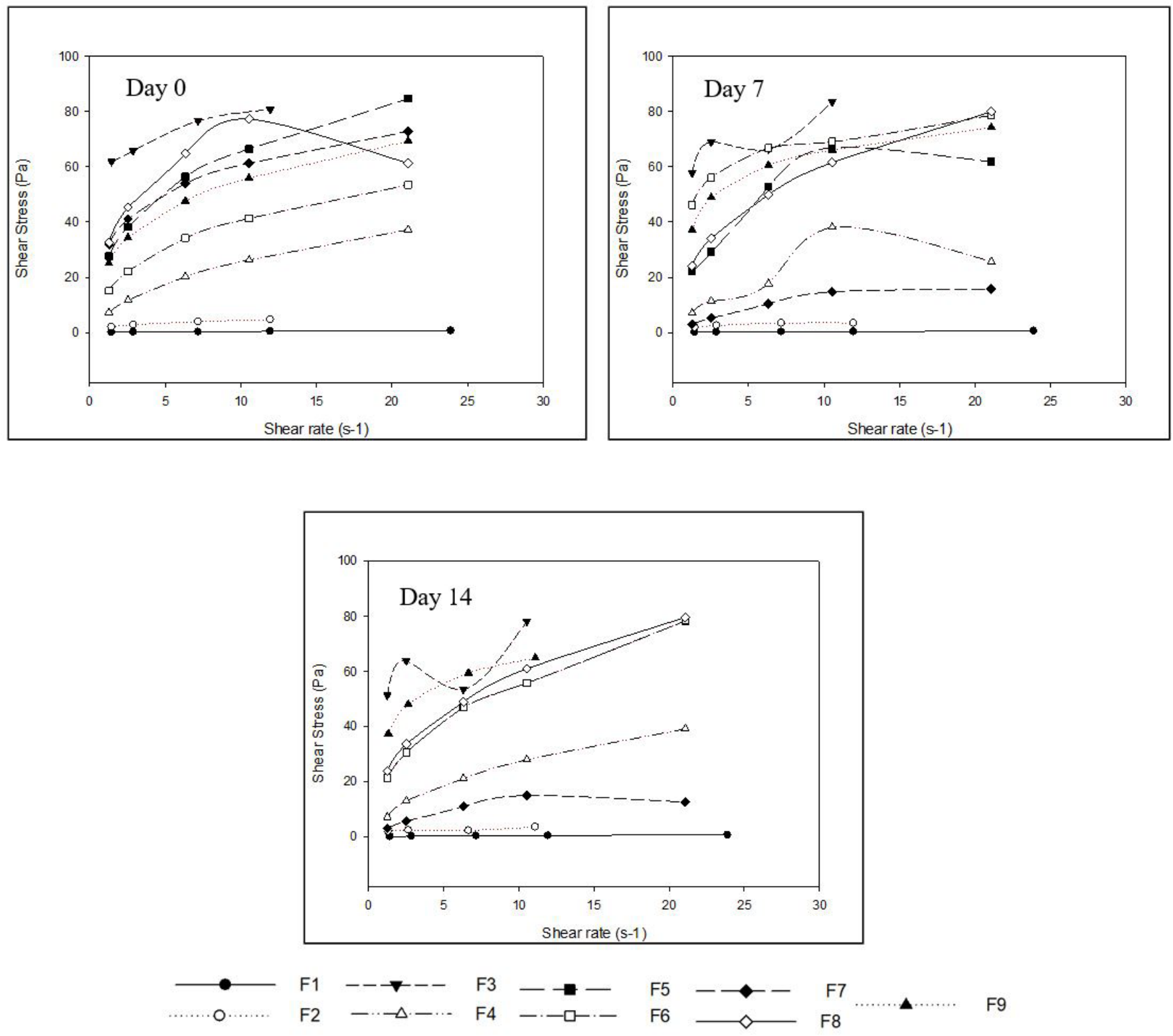

Figure 1. Flow curves for dairy beverages on (a) day 0 , (b) day 7, (c) and day 14, during refrigerated storage $\left(4^{\circ} \mathrm{C}\right)$.

the most important sensory descriptors that could contribute to distinguishing the beverages made in this experiment. The selected sensory characteristics corresponded to appearance (yellow and fawn colorations), smell (fermented and vanilla), taste (milk, sweet, and intense taste) and texture (liquid, sticky, dense and thick).

The first two axes of the Principal Component Analysis accounted for $71.2 \%$ of the variance (Figure 2 ). The results of the principal component analysis showed a high correlation between the viscosity determined instrumentally and the sensory attributes of thick and fermented smell, which were related to samples F3, F6 and F9, all of which contained the highest concentration of gum. Acidity was higher in samples F2, F5 and F8, which contained a medium concentration of gum and were perceived as viscous by consumers. The $\mathrm{pH}$ and total soluble solids show low contributions in terms of viscosity and acidity and were therefore less associated with samples or sensory characteristics. Since the instrumentally measured viscosity was negatively correlated with the sensory attributes of liquid, sweet taste, and vanilla smell as well as being highly correlated with beverages made with lower and medium concentrations of gum (F1 and F4), it is possible to conclude that these samples were perceived contrarily to those made with higher gum content.

\subsection{Sensory acceptance}

Four clusters of consumers were identified when a K-means Cluster Analysis was applied to analyze the responses of overall liking for flavored whey beverages. There were different liking patterns for products between the various groups of consumers. Cluster 1 comprised 33 subjects who gave higher liking values 


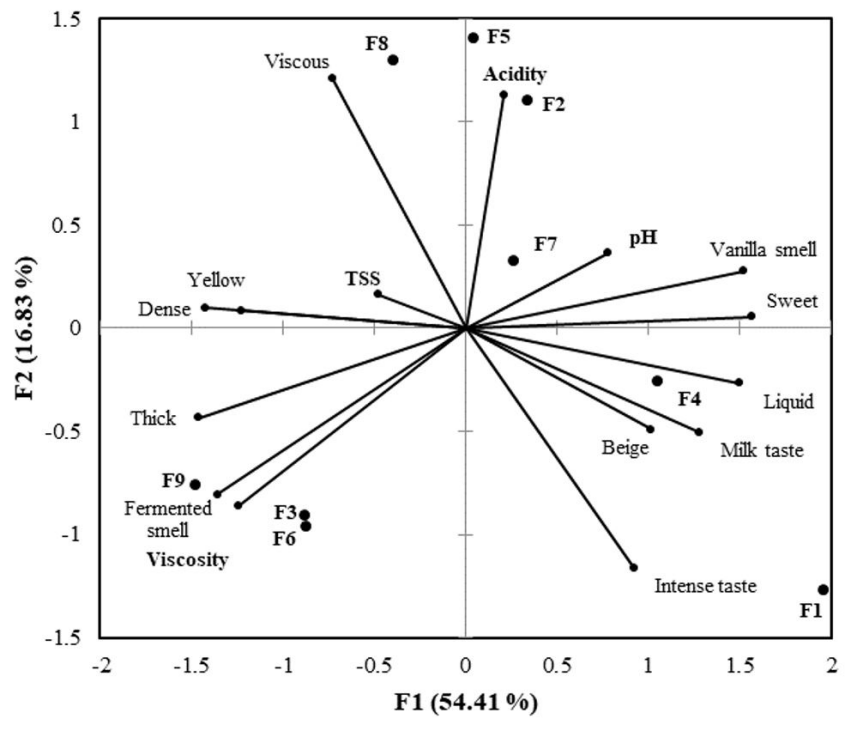

Figure 2. Principal component analysis of physicochemical data obtained instrumentally, and sensory data obtained by the frequency of mentions of attributes in CATA questions. F1, F4, F7. Formulations with low gum content. F2, F5, F8. Formulations with medium gum content. F3, F6, F9. Formulations with high gum content.

to flavored beverages made from whey with lower gum and inulin content, followed by beverages with low gum content and medium to high inulin content, as well as beverages with medium gum content and low to medium inulin content, meaning that it was very important that the samples were perceived as liquid by these consumers. The participants of cluster $2(n=43)$ considered the beverages with medium to high gum content as unacceptable; their ratings decreased as the sweetness in samples increased. Therefore, for participants in this cluster, the sweetness in products was more important than the viscosity, although they preferred the lowest quantity of inulin in samples. On the other hand, participants from the fourth cluster $(n=22)$ considered samples with medium to low inulin content and any level of gum content more acceptable but preferred the samples with more gum and medium inulin content. Finally, the subjects from the third cluster $(n=22)$ did not show strong acceptance for the beverages and only considered the sample with medium gum content and higher inulin content as acceptable.

The sensory characteristics of taste and texture contribute significantly to defining food preferences (Kourouniotis et al., 2016; Rosenthal, 2010). According to the results observed for acceptance, consumers from clusters 1 and 2 (63.3\% of the sample) considered the liquid samples with lower to medium sweetness as the best. On the other hand, participants from cluster 4 (18.3\% of participants) considered the most viscous samples with medium sweetness levels as the most acceptable, while $18.7 \%$ of the participants preferred the sweetest beverages with medium viscosity.

The results obtained from the acceptance tests are interesting for the development of the product tested in this experiment. Liking of sweet-tasting foods is innate, universal, and expected (Drewnowski et al., 2012). An emphasis is placed on incorporating sweetness into food products where this attribute is an expected characteristic (Baharuddin \& Sharifudin, 2015), but there is a threshold or maximum acceptance after which a higher concentration of sweetness is expected to be rejected (Lawless \& Heymann, 2010; Jayasinghe et al., 2017). This is true for most consumers, but concentrations for maximum acceptance will always vary between consumers with different points of view (Johansen et al., 2010) and other several inter-individual differences, including sweetness sensitivity (Drewnowski et al., 2012; Jayasinghe et al., 2017). Determining the highest point in the $\mathrm{u}$-shaped curve obtained when concentration and liking degrees are related is an important issue, as the maximum point could vary between different customer segments. In this study, the highest sweetness level for maximum liking was different for each customer segment. However, most subjects agree that the beverages should have a low to medium gum content in (clusters 2 and 4), while the inulin content should be low to medium (clusters 2 and 1) to satisfy the highest proportion of consumers based on the experimental data.

\subsection{Sensory characteristics of flavored whey beverages}

Figure 3 shows the spatial distribution of products and their associated characteristics according to the participants' feedback during the study. A high percentage of variance $(94.84 \%)$ can be attributed to the first two factors. According to the responses provided by most participants, an ideal whey protein beverage should be liquid, sweet, with an intense taste, a vanilla smell, and milky taste. In contrast, the presence of a fermented smell, yellow coloration, and increased thickness in beverages was considered unacceptable and resulted in the samples with a higher gum content being rejected. Subjects also indicated that samples with higher fluid characteristics came closer to the ideal product. It is possible that when the products had higher liquid characteristics, it was easier to stimulate the receptor proteins located in the taste buds, affecting the intensity perception of compounds responsible for the sweet and smell attributes in the beverages. The results obtained in this experiment partially concur with those obtained by Janiaski et al. 2016, who determined acceptability and drivers of liking for yogurts as well as fermented and non-fermented whey beverages. Their report states that these beverages were highly accepted and their consumer's ideal strawberry-flavored whey beverage should have a sweet taste and intermediate color and viscosity values, as well as a low intensity acidic taste and aroma. Unfortunately, their study does not show any instrumentally measured texture values for beverages to compare the viscosity in their samples with those obtained in this report. On the other hand, it is worth mentioning that the viscosity expressed in their experiment could be biased because of a contrast effect when comparing yogurts and whey beverages as these samples were tested in the same session.

Formulations with medium gum content with any quantity of added inulin (F2, F5, and F8) were perceived as more viscous and acidic than those made with a lower gum content. The beverages made with the highest gum content (F3, F6, and F9) were associated with a fermented smell and perceived as the thickest among all the samples by consumers. 


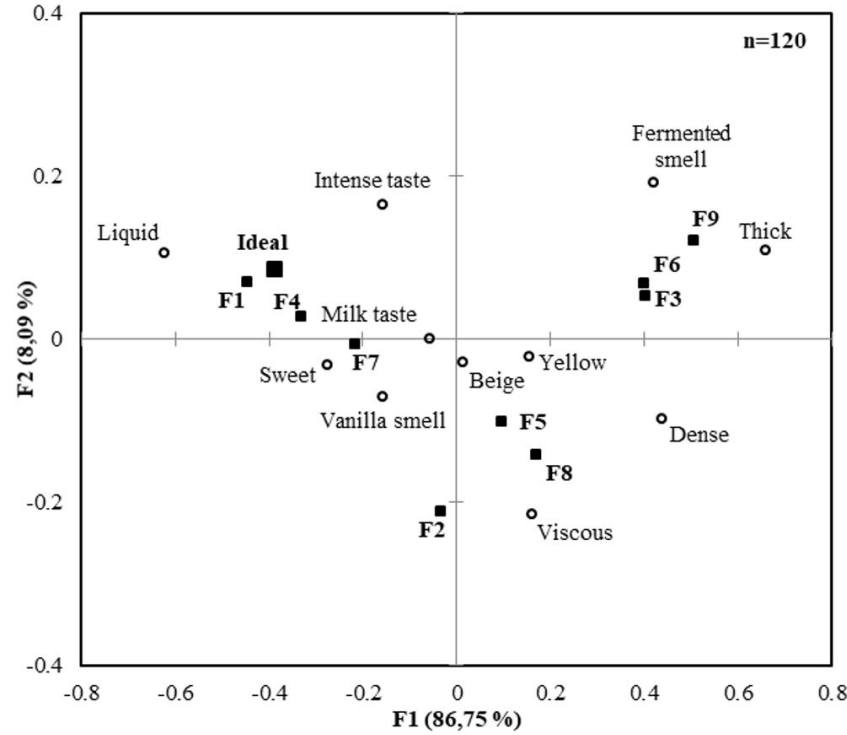

Figure 3. Distribution of flavored whey beverages and attributes by frequency of mentions by consumers answering CATA questions. F1, F4, F7. Formulations with low gum content. F2, F5, F8. Formulations with medium gum content. F3, F6, F9. Formulations with high gum content.

These last-mentioned attributes were highly correlated with the instrumentally determined viscosity values (Figure 3 ). According to the instrumentally determined values, the least viscous beverages were samples 1 and 4 , which is what was perceived by consumers, who indicated that those samples had the strongest liquid characteristics.

Despite the differences in total acidity and total soluble solids determined instrumentally, there was no association between these characteristics and the attributes perceived and reported by the consumers who completed the CATA questionnaire. In contrast, increased viscosity in samples was associated with dense, thicker, and more viscous products. Furthermore, while the samples were more viscous, they were also associated with a fermented smell, as well as a less intense vanilla smell and milky taste. These attributes were perceived contrarily when the viscosity value decreased in the samples.

\section{Conclusions}

The use of whey as a byproduct from the making process of cheese is a feasible alternative ingredient in the production of functional beverages. According to acceptance tests and a CATA questionnaire, it is possible to obtain a cajeta-flavored whey-beverage which is widely accepted by a large section of consumers and with functional characteristics when added with inulin.

\section{References}

Ares, G., \& Jaeger, S. R. (2013). Check-all-that-apply questions: influence of attribute order on sensory product characterization. Food Quality and Preference, 28(1), 141-153. http://dx.doi.org/10.1016/j. foodqual.2012.08.016.
Arranz, E., Corrochano, A. R., Shanahan, C., Villalva, M., Jaime, L., Santoyo, S., Callanan, M. J., Murphy, E., \& Giblin, L. (2019). Antioxidant activity and characterization of whey protein-based beverages: Effect of shelf life and gastrointestinal transit on bioactivity. Innovative Food Science \& Emerging Technologies, 57, 102209. http:// dx.doi.org/10.1016/j.ifset.2019.102209.

Association of Official Analytical Chemists - AOAC. (1980). Official methods of analysis (13th ed., 240 p.). Washington: AOAC.

Baharuddin, A. R., \& Sharifudin, M. S. (2015). The impact of geographical location on taste sensitivity and preference. International Food Research Journal, 22(2), 731-738.

Baljeet, S. Y., Ritika, B. Y., \& Sarita, R. (2013). Studies on development and storage of whey-based pineapple (Ananas comosus) and bottle gourd (Lagenaria siceraria) mixed herbal beverage. International Food Research Journal, 20(2), 607-612.

Berget, I. (2018). Statistical approaches of consumer segmentation. In G. Ares \& P. Varela (Eds.), Methods in consumer research: new approaches to classic methods (Woodhead Publishing Series in Food Science, Technology and Nutrition, pp. 731-738). Duxford: Woodhead Publishing. http://dx.doi.org/10.1016/B978-0-08-102089-0.00014-5.

Brookfield. (2011). Viscosimeter Handbook, DV-II + Pro Operating Instructions (Manual No. M03-165-F0612, Vol. 8139). Retrieved from www.brookfieldengineering.com

Bruzzone, F., Vidal, L., Antúnez, L., Giménez, A., Deliza, R., \& Ares, G. (2015). Comparison of intensity scales and CATA questions in new product development: sensory characterisation and directions for product reformulation of milk desserts. Food Quality and Preference, 44, 183-193. http://dx.doi.org/10.1016/j.foodqual.2015.04.017.

Castro, F. P., Cunha, T. M., Ogliari, P. J., Teófilo, R. F., Ferreira, M. M. C., \& Prudêncio, E. S. (2009). Influence of different content of cheese whey and oligofructose on the properties of fermented lactic beverages: study using response surface methodology. Lebensmittel-Wissenschaft + Technologie, 42(5), 993-997. http:// dx.doi.org/10.1016/j.lwt.2008.12.010.

Chatterrjee, G., De Neve, J., Dutta, A., \& Das, S. (2015). Formulation and statistical evaluation of a ready-to-drink whey based orange beverage and its storage stability. Revista Mexicana de Ingeniería Química, 14(2), 253-264.

Chavan, R. S., Kumar, A., \& Nalawade, T. (2015a). Whey Bases Beverage: Its functionality, formulations, health benefits and Applications. Food Processing \& Technology, 6(10), 1-8.

Chavan, R. S., Nalawade, T., \& Kumar, A. (2015b). Studies on the development of whey bases mango beverage. Research \& Reviews: Journal of Food and Dairy Technology, 3(2), 1-10.

Dhamsaniya, N. K., \& Varshney, A. K. (2013). Development and evaluation of whey based rts beverage from ripe banana juice. Journal of Food Processing \& Technology, 04(02). http://dx.doi. org/10.4172/2157-7110.1000203.

Drewnowski, A., Mennella, J. A., Johnson, S. L., \& Bellisle, F. (2012). Sweetness and food preference. The Journal of Nutrition, 7(6), 11421148. http://dx.doi.org/10.3945/jn.111.149575. PMid:22573785.

Gomes, J. J. L., Duarte, A. M., Batista, A. S. M., Figueiredo, R. M. F., Sousa, E. P., de Souza, E. L., \& Queiroga, R. (2013). Physicochemical and sensory properties of fermented dairy beverages made with goat's milk, cow's milk and a mixture of the two milks. LebensmittelWissenschaft + Technologie, 54(1), 18-24. http://dx.doi.org/10.1016/j. lwt.2013.04.022.

Grom, L. C., Rocha, R. S., Balthazar, C. F., Guimarães, J. T., Coutinho, N. M., Barros, C. P., Pimentel, T. C., Venâncio, E. L., Collopy, I. Jr., Maciel, P. M. C., Silva, P. H. F., Granato, D., Freitas, M. Q., 
Esmerino, E. A., Silva, M. C., \& Cruz, A. G. (2020). Postprandial glycemia in healthy subjects: which probiotic dairy food is more adequate? Journal of Dairy Science, 103(2), 1110-1119. http://dx.doi. org/10.3168/jds.2019-17401. PMid:31785881.

Guimarães, J. T., Keven Silva, E., Senaka Ranadheera, C., Moraes, J., Raices, R. S. L., Silva, M. C., \& Cruz, A. G. (2019). Effect of highintensity ultrasound on the nutritional profile and volatile compounds of a prebiotic soursop whey beverage. Ultrasonics Sonochemistry, 55, 157-164. http://dx.doi.org/10.1016/j.ultsonch.2019.02.025. PMid:30853535.

Guimarães, J. T., Silva, E. K., Costa, A. L. R., Cunha, R. L., Freitas, M. Q., Meireles, M. A. A., \& Cruz, A. G. (2018). Manufacturing a prebiotic whey beverage exploring the influence of degree of inulin polymerization. Food Hydrocolloids, 77, 787-795. http://dx.doi. org/10.1016/j.foodhyd.2017.11.021.

Ha, E., \& Zemel, M. B. (2003). Functional properties of whey, whey components, and essential amino acids: mechanisms underlying health benefits for active people. The Journal of Nutritional Biochemistry, 14(5), 251-258. http://dx.doi.org/10.1016/S0955-2863(03)00030-5.

Ismail, A. E., Abdelgader, M. O., \& Ali, A. A. (2011). Microbial and chemical evaluation of Whey-Based Mango beverage. Advance Journal of Food Science and Technology, 3(4), 250-253.

Janiaski, D. R., Pimentel, T. C., Cruz, A. G., \& Prudencio, S. H. (2016). Strawberry-flavored yogurts and whey beverages: what is the sensory profile of the ideal product? Journal of Dairy Science, 99(7), 52735283. http://dx.doi.org/10.3168/jds.2015-10097. PMid:27157581.

Jayasinghe, S. N., Kruger, R., Walsh, D. C. I., Cao, G., Rivers, S., Richter, M., \& Breier, B. H. (2017). Is sweet taste perception associated with sweet food liking and intake? Nutrients, 9(7), 1-19. http://dx.doi. org/10.3390/nu9070750. PMid:28708085.

Johansen, S. B., Hersleth, M., \& Næs, T. (2010). A new approach to product set selection and segmentation in preference mapping. Food Quality and Preference, 21(2), 188-196. http://dx.doi.org/10.1016/j. foodqual.2009.05.007.

Kourouniotis, S., Keast, R. S. J., Riddell, L. J., Lacy, K., Thorpe, M. G., \& Cicerale, S. (2016). The importance of taste on dietary choice, behaviour and intake in a group of young adults. Appetite, 103, 1-7. http://dx.doi.org/10.1016/j.appet.2016.03.015. PMid:26972352.

Lawless, H. T., \& Heymann, H. (2010). Acceptance testing. In H. T. Lawless \& H. Hermann (Eds.), Sensory evaluation of food: principles and practices (2nd ed., Vol. 20, No. 3). New York: Springer. https:// doi.org/10.1007/978-1-4419-6488-5_20.

Li, B., Hayes, J. E., \& Ziegler, G. R. (2015). Maximizing overall liking results in a superior product to minimizing deviations from ideal ratings: an optimization case study with coffee-flavored milk. Food Quality and Preference, 42(1), 27-36. http://dx.doi.org/10.1016/j. foodqual.2015.01.011. PMid:26005291.

Molero, M., \& Briñez, W. J. (2018). Probiotics consumption increment through the use of whey-based fermented beverages (pp. 115-132). London: Intechopen. http://dx.doi.org/10.5772/intechopen.72362.
Monteiro, S. H. M. C., Silva, E. K., Guimarães, J. T., Freitas, M. Q., Meireles, M. A. A., \& Cruz, A. G. (2020). High-intensity ultrasound energy density: How different modes of application influence the quality parameters of a dairy beverage. Ultrasonics Sonochemistry, 63, 104928. http://dx.doi.org/10.1016/j.ultsonch.2019.104928. PMid:31952002.

O’Mahony, M., \& Wichchukit, S. (2017). The evolution of paired preference tests from forced choice to the use of 'No Preference' options, from preference frequencies to $\mathrm{d}^{\prime}$ values, from placebo pairs to signal detection. Trends in Food Science and Technology, 66, 146-152. https://doi.org/10.1016/j.tifs.2017.05.017.

Panghal, A., Kumar, V., Dhull, S. B., Gat, Y., \& Chhikara, N. (2017). Utilization of dairy industry waste-whey in formulation of papaya RTS beverage. Current Research in Nutrition and Food Science, 5(2), 168-174. http://dx.doi.org/10.12944/CRNFSJ.5.2.14.

Parente, E., Manzoni, A. V., \& Ares, G. (2011). External preference mapping of commercial antiaging creams based on consumer's responses to a check-all-that-apply question. Journal of Sensory Studies, 26(2), 158-166. http://dx.doi.org/10.1111/j.1745-459X.2011.00332.x.

Park, W. Y., \& Haenlein, F. W. G. (2013). Milk and dairy products in human nutrition: production, composition and health (1st ed., Chap. 19, Condensed and powered milk). Chichester: Wiley-Blackwell.

Rao, V. A. (2001). The prebiotic properties of oligofructose at low intake levels. Nutrition Research, 21(6), 843-848. http://dx.doi.org/10.1016/ S0271-5317(01)00284-6.

Roberfroid, M. B. (1999). Concepts in functional foods: the case of inulin and oligofructose. The Journal of Nutrition, 129(7, Suppl), 1398S-1401S. http://dx.doi.org/10.1093/jn/129.7.1398S. PMid:10395606.

Rosenthal, A. J. (2010). Texture profile analysis: how important are the parameters? Journal of Texture Studies, 41(5), 672-684. http:// dx.doi.org/10.1111/j.1745-4603.2010.00248.x.

Sakhale, B. K., Pawar, V. N., \& Ranveer, R. (2012). Studies on the development and storage of whey based RTS beverage from mango Cv. Kesar. Journal of Food Processing \& Technology, 3(3), 1000148. http://dx.doi.org/10.4172/2157-7110.1000148.

Shukla, M. (2012). Development of probiotic beverage from whey and pineapple juice. Journal of Food Processing \& Technology, 4(2), 4-7. http://dx.doi.org/10.4172/2157-7110.1000206.

Silveira, E. O. D., Lopes Neto, J. H., Silva, L. A., Raposo, A. E. S., Magnani, M., \& Cardarelli, H. R. (2015). The effects of inulin combined with oligofructose and goat cheese whey on the physicochemical properties and sensory acceptance of a probiotic chocolate goat dairy beverage. Lebensmittel-Wissenschaft + Technologie, 62(1), 445-451. http://dx.doi.org/10.1016/j.lwt.2014.09.056.

Thamer, K. G., \& Penna, A. L. B. (2006). Characterization of functional dairy beverages fermented by probiotics and with the addition of prebiotics. Food Science and Technology, 26(3), 589-595. http:// dx.doi.org/10.1590/S0101-20612006000300017.

Yasmin, A., Butt, M. S., Sameen, A., \& Shahid, M. (2013). Physicochemical and amino acid profiling of cheese whey. Pakistan Journal of Nutrition, 12(5), 455-459. http://dx.doi.org/10.3923/pjn.2013.455.459. 